\title{
Status of Ichneumonidae (Hymenoptera: Ichneumonoidea) in Cuba
}

\author{
José L. Fernández Triana ${ }^{1}$, Horacio Grillo Ravelo² \& Mabel López ${ }^{3}$ \\ 1 Centro Oriental de Ecosistemas y Biodiversidad, Departamento de Zoología, Santiago de Cuba; \\ jlft1971@yahoo.com \\ 2 Centro de Investigaciones Agropecuarias, Universidad Central de Las Villas, Santa Clara, Cuba. \\ 3 Centro de Investigaciones en Ecosistemas Costeros, Cayo Coco, Ciego de Ávila, Cuba.
}

Received 02-VI-2002. C Corrected 16-VI-2004. Accepted 26-I-2005.

\begin{abstract}
Current understanding of Cuban ichneumonids (Hymenoptera: Ichneumonoidea) is analysed. A new Subfamily (Tersilochinae) including 13 genera and two species are first reports for Cuba. In contrast with Braconidae, the sister group, the ichneumonids are poorly known because of the lack of local taxonomists and bacause nets, rather than interception, light and yellow pan traps have been used. Using Ophioninae as a reference, and comparing the percentage of ophionines in the fauna of Costa Rican ichneumonids, the ratio of species of Costa Rican to Cuban Ophioninae and the increase in the number of described Cuban ophionines, we suggest that actual Cuban biodiversity in this group may be between 400 and 600 species. Rev. Biol. Trop. 54 (3): 821-827. Epub 2006 Sept. 29.
\end{abstract}

Key words: Ichneumonidae, taxonomy, biodiversity, Cuba.

When Pastor Alayo finished his Catalog of Cuban Hymenoptera in 1970 it encompassed 398 genera and 914 species of Hymenoptera (Alayo 1973). Recently, Portuondo and Fernández (2003) updated the information available, recording 542 genera and 1156 species, but the numbers are constantly growing. According to the Alayo data, Ichneumonoidea accounted for about one quarter of all Hymenoptera species reported for the country (27\%), but since then a different pattern has been found in its two families.

Thirty years ago, 40 genera and 104 species of Braconidae were recorded. As Alayo predicted in the introduction of his Catalog, the braconids have increased significantly; the total number of genera known today has doubled since 1970 (see a summary in Fernández and Portuondo 2001, updated in Portuondo and Fernández 2003).

Figures for 1970 established Ichneumonidae as the largest hymenopteran family with 69 genera (followed by Braconidae) and 140 species (followed by Formicidae). However, in subsequent years there were few contributions made to the study of Cuban ichneumonids. Alayo and Tzankov (1974a, b) and Tzankov and Alayo (1974) revised Cryptinae in part, as Gelinae, and described eight new species. Dasch (1974) described four new species of Mesochorinae in Cuba in his Neotropical study of the subfamily. Hochmut and Manso (1975) reported Mesostenus sp. (Cryptinae) and Trichomma sp. (Anomaloninae) as parasitoids of the lepidopteran Hypsipyla grandella Zeller, although they did not realize that both genera were new records for the country. Porter (1984) studied Laticinctus group of the genus Thyreodon in the Northern Neotropics and described a new species for Cuba and Bahamas. Finally, Gauld (1988) described three new species and cited two new records of Enicospilus for Cuba in his Mesoamerican revision of the Ophioninae subfamily. 
A compilation of this data reveals that Cuban ichneumonids comprise 72 genera and 154 species and during the last 15 years no more research on the group has been done. The present work analyses some reasons for this bias, reports new genera and species for the country, and offers a first attempt to estimate Ichneumonidae biodiversity in Cuba.

\section{MATERIALS AND METHODS}

During a comprehensive review of Cuban Ophioninae (Fernández-Triana 2005), the senior author was able to study a limited amount of material from other Ichneumonidae subfamilies housed in major collections across the country. According to a first estimate (Fernández, unpublished data) more than 5000 pinned specimens of Ichneumonidae may be housed in Cuban entomological collections, but many more are stored in alcohol. For the report 1000 specimens were studied. The following abbreviations have been used:

BIOECO Centro Oriental de Ecosistemas y Biodiversidad, Santiago de Cuba.

CIEC Centro de Investigaciones en Ecosistemas Costeros, Cayo Coco, Ciego de Avila.

IES Instituto de Ecología y Sistemática, Ciudad de La Habana.

MNHNCu Museo Nacional de Historia Natural, Ciudad de La Habana.

UCLV Universidad Central de Las Villas, Santa Clara.

For each new record found the information is presented in the following order: "Locality, Municipality, Province; Date; Collecting Device and/or Collector Name (number and sex of specimens, Institution)". However, some labels had misleading information about specimens (including abbreviations not explained in collection catalogues or other data sources) and were only recorded with meaningful data when possible and/or the comment: "no further data".
Estimates of Ichneumonidae biodiversity in Cuba were extrapolated using data for Costa Rica, the only Neotropical country with sufficient information on the group (Gauld 1988, 1991, 1997, 2000, Gauld et al. 1998, 2002, Gauld and Janzen 2004, Gauld, pers. com.). Nonetheless, Ophioninae was the only subfamily with enough data for both countries (Gauld 1988, Gauld and Janzen 2004, FernándezTriana 2005) and it was therefore used to ask the following three important questions:

- What is the percentage of ophionines in the fauna of Costa Rican ichneumonids?

- What is the ratio of species of Costa Rican to Cuban Ophioninae?

- What has been the increase of Cuban ophionines, comparing previous studies (Alayo 1973, Gauld 1988) to the recent findings of Fernández-Triana (2005)?

These values were then used to estimate the total number of Cuban Ichneumonidae species by extrapolation.

\section{RESULTS}

A new Subfamily (Tersilochinae), 13 genera and two species were first records for Cuba:

Subfamily Cremastinae:

- Trathala sp. Laguna Emperador, Cayo Coco, Ciego de Avila; III-2000; Malaise trap (1 \&, CIEC). This is a very large cosmopolitan genus with more than 40 species in the Neotropical region, but far more occur in tropical America (Townes and Townes 1966, Gauld 2000).

Subfamily Cryptinae:

- Cestrus sp. La Mula, Guamá, Santiago de Cuba; no further data (1 or, BIOECO). Cayo Coco, Ciego de Avila; V-1994; E. Portuondo (1 Ơ', BIOECO). Ciénaga de Zapata, Matanzas; II-1995; Malaise trap (1 O․ BIOECO). A large neotropical genus (Townes 1970a, Wahl 1999). 
- Gelis sp. Santa Clara, Villa Clara; no further data (1 $ᄋ$, UCLV). A very large genus, worldwide (Townes 1970a, Wahl 1999).

- Platymistax sp. El Toldo, Moa, Holguín; X-1996 \& IX-1998; yellow pan trap, A. Fong (3 $\sigma^{x}$, BIOECO). A large genus of pantropic distribution (Townes 1970a, Wahl 1999).

\section{Ichneumoninae:}

- $\quad$ Narthecura sp. Peralejo, Bayamo, Granma; VII-1984; P. Espinosa (1 \&, BIOECO).

- Trogomorpha sp. El Olimpo, Gran Piedra, Santiago de Cuba; II-2000; J. Reyes (1 O', BIOECO). These two genera are restricted to the New World (Wahl 1999).

\section{Orthocentrinae:}

- Megastylus sp. La Isabelica, Gran Piedra, Santiago de Cuba; I-1996; flight interception trap (1 $\sigma^{7}$, BIOECO). This is a very large and worldwide genus, with the largest concentration of species in the Neotropical region (Townes 1970b, Wahl 1999).

\section{Ophioninae:}

- Rhynchophion flammipennis (Ashmead). Siboney, Santiago de Cuba; VI-1947; P. Alayo (1 9 , MNHNCu). Cuba, no further data, J. Gundlach (1 $\circ$, IES). A small genus, previously restricted to the southern part of the USA and the Neotropical region south to Brazil (Townes and Townes 1966, Gauld 1988, Gauld and Janzen 2004). Present record is the first for the Caribbean islands. $R$. flammipennis is widely distributed from USA to Ecuador and possibly northern Argentina. The collection season for Cuban specimen coincides with that of Costa Rica, where the species is collected between June and early August (Gauld and Janzen 2004).

\section{Pimplinae:}

- Polysphincta sp. Pico Cuba, Sierra Maestra, Guamá, Santiago de Cuba; no further data. ( $1 \sigma^{7}$, BIOECO). This is a moderately small Holoartic and Neotropical genus, with about 30 described species (Gauld 1991, Gauld et al. 1998).

- Scambus sp. Sitio Viejo, Cayo Coco, Ciego de Avila; II-1997; Malaise trap (1 $\sigma^{\gamma}$, CIEC). This is a large genus represented in all regions except Australia. In the New World there are about 35 described species, with most in North America (including Mexico) (Gauld 1991, Gauld et al. 1998).

- Zaglyptus varipes incompletus (Cresson) Yabú, Santa Clara, Villa Clara; IX-1971; H. Grillo (1q, UCLV). This species is reported for first time to tropical America (Gauld et al. 1998). The status of this genus in Cuba needs further studies. Interestingly, Townes (1960) mentions a specimen of $Z$. pictilis that he deposited at the United States National Museum and collected in a plane from Havana, Cuba in 1952.

Tersilochinae:

- Allophrys sp. Jardín Botánico, Santiago de Cuba; XII-1995; E. Portuondo (2 $\sigma^{\top}$, BIOECO). Worldwide except Paleartic (Wahl 1999). The genus is most common in the Neotropical region, where the only described species, A. oculatus (Ashmead), has been cited from the West Indies (Townes 1970b).

- Stethantyx sp. 1. Santa Cruz del Norte, La Habana; VIII-1990; H. Pérez (1 o', MNHNCu).

- Stethantyx sp. 2. Topes de Collantes, Trinidad, Sancti Spiritus; XI-2001; light trap (1 ○’, BIOECO). Townes (1970b) described the genus and one Neartic species, but he also mentioned 23 undescribed species from the Neotropical region.

The new ichneumonids reported here represent a significant increase $(20.3 \%)$ in relation to what was previously known. Present information on Ichneumonidae makes it once again the most diverse Hymenoptera family in Cuba, at both the genera (85) and species level (about 180). However, this study is merely a first step; the material examined represents only a small fraction of the specimens housed 
in Cuban collections. Further investigation and collecting efforts will surely render many more genera and species for the country.

\section{DISCUSSION}

In the studies and inventories of Hymenoptera biodiversity carried out in Cuba during last 30 years (García et al. 1973, Botta and Viña 1982, Arrianza and Melián 1983, Anonymous 1984, Fernández 1994, Portuondo et al. 1994, Portuondo and Garcés 1994, Portuondo 1998, 2001, Fernández et al. 2002), many new genera and species in all major groups of the order have been reported, with the noteworthy exception of Ichneumonidae.

Table 1 shows the proportion of Ichneumonoidea and Braconidae reported in major studies done on Hymenoptera. The species number for Braconidae increased significantly after the work of Marsh et al. (1987) was made available to Cuban researchers. The low number of braconids reported in Portuondo (1998, 2001) is an artifact because the family was not thoroughly studied in those papers.

In contrast, the ichneumonids remained approximately at the same percentage and even diminished in some of the most recent works (eg Portuondo and Garcés 1994, Portuondo 1998). It has only been since 2001, when research on Ichneumonidae began again in Cuba, that the figures have also increased.
These figures must be viewed as a conservative estimate because the inventories are far from complete (Fernández, 2005) and many groups, both within Ichneumonoidea and outside of it, contain large numbers of unidentified species that could ultimately change the final percentages.

Without a doubt, the unfavorable situation of ichneumonids is clear and there are several reasons for it. The first is that due to the lack of Cuban hymenoptera specialists, the little research that has been done on this group has depended on the initiative of foreign specialists and in fact, no studies have been carried out in the country during the last 30 years on Ichneumonidae. The second major reason is the bias in the collecting efforts that have for the most part only used entomological nets. Interception, light and yellow pan traps have been used in a lesser extent and Malaise traps have almost never been employed (Fernández 2002). Malaise traps are probably the best device for collecting large sets of ichneumonids, especially of the rarest species (eg Gauld 1991, Hanson and Gauld 1995, Gauld et al. 1998). Lastly, the absence of basic scientific literature needed for specimen identification, with the exception of the most common species, has been a constant constraint for those studying the order in Cuba.

In Braconidae, the sister group, the situation is completely different, with several researchers in the country having the key to Neartic

TABLE 1

Number of species (No.) and percentage (\%) of Ichneumonoidea recorded in selected Cuban studies of Hymenoptera biodiversity

\begin{tabular}{lcccccccccc}
\multirow{2}{*}{ Ichneumonoidea } & & $(1)$ & $(2)$ & $(3)$ & $(4)$ & $(5)$ & $(6)$ & $(7)$ & $(8)$ & $(9)$ \\
& & 1973 & 1982 & 1983 & 1984 & 1994 & 1994 & 1998 & 2001 & 2002 \\
\multirow{2}{*}{ Braconidae } & No. & 2 & 2 & 5 & 9 & 29 & 23 & 3 & 10 & 36 \\
& $\%$ & 2.0 & 2.2 & 5.0 & 8.0 & 14.7 & 13.9 & 1.1 & 3.6 & 12.4 \\
Ichneumonidae & No. & 22 & 7 & 11 & 21 & 17 & 3 & 10 & 37 & 53 \\
& $\%$ & 21.6 & 7.7 & 10.9 & 18.6 & 8.6 & 1.8 & 3.6 & 13.1 & 18.3
\end{tabular}

Notes: (1) García et al. 1973, (2) Botta and Viña 1982, (3) Arrianza and Melián 1983, (4) Anonymous 1984, (5) Fernández 1994, (6) Portuondo et al. 1994, (7) Portuondo and Garcés 1994, (8) Portuondo 1998, 2001, (9) Fernández et al. 2002. 
genera of Marsh et al. (1987) and/or the New World keys of Wharton et al. (1998), which has allowed certain advance in this group in the identification of braconids in the biodiversity studies carried out in recent years in Cuba.

It is very difficult to assess the true extent of Ichneumonidae fauna in Cuba because there are many gaps in the data available; relatively large sets of unidentified specimens remain housed in collections throughout the country and a significant number of ecosystems have been poorly sampled. Any figure can only be seen as a very preliminary estimate.

Table 2 shows a comparison between Cuban and Costa Rican fauna regarding total number of species, as well as major subfamilies. Cuba has 11 subfamilies fewer and several of the extant have few records related to the species actually housed in collections (eg Banchinae, Campopleginae, Cremastinae, Ichneumoninae, Tryphoninae, as well as Cryptinae and Pimplinae).

There has been a significant bias favoring the study of Costa Rican ichneumonids, despite the fact that Cuba is about twice the size of Costa Rica, the latter has mountains almost twice as

TABLE 2

Comparison between Cuba and Costa Rica Ichneumonidae faunas

$\begin{array}{lccc}\text { Major subfamilies } & \text { Cuba } & \text { Costa Rica } & \begin{array}{c}\text { Ratio Costa Rica } \\ \text { /Cuba }\end{array} \\ \text { Cryptinae } & 39 & +500 & 13 / 1 \\ \text { Ophioninae } & 34 & \cong 200\left(^{*}\right) & 6 / 1 \\ \text { Pimplinae } & 28 & 184 & 6.5 / 1 \\ \text { Ichneumoninae } & 21 & 300-400 & 14-19 / 1 \\ \text { Campopleginae } & 15 & 150 & 10 / 1 \\ \text { Cremastinae } & 14 & 142 & 10 / 1 \\ \text { Tryphoninae } & 10 & 91 & 9 / 1 \\ \text { Banchinae } & 3 & 253 & 80 / 1 \\ \text { Total of subfamilies } & 14 & 25 & ---- \\ \text { Total of species } & \cong 180 & \cong 4000\left(^{*}\right) & 22 / 1\end{array}$

Notes: Data sources are Gauld papers (see text), FernándezTriana (2005) and present paper. (*) Current estimates, from Gauld (pers. comm.). high, has more ecosystems, and has far less habitat degradation. Besides, ichneumonids have been intensively sampled throughout Costa Rica for many years and with a variety of collecting devices (Gauld 1991, Hanson and Gauld 1995). In addition, world authorities have extensively studied the material gathered, making it the best understood family in the Neotropics (Gauld et al. 2002). Therefore, the real proportion of species between these two countries should not be 22 to one as results presently show.

Ophioninae represents 4-5\% of all Costa Rican ichneumonids. If the same percentage is expected for Cuba, then Cuba should have an estimate of 700 and 800 species of Ichneumonidae.

On the other hand, and according to Table 2, the proportion Costa Rican to Cuban species of Ophioninae is 6:1. Using a conservative ratio to the whole family (8:1), there should be approximately 500 Cuban Ichneumonidae, based on the Costa Rican total number of species.

After Fernández-Triana (2005), identification of Cuban species of Ophioninae increased from 20 up to 34 (or $70 \%$ ). If the same increase is expected for the rest of the subfamilies, then slightly more than 300 species should be the final result. This estimate must be reanalyzed because two revisions (Porter 1984, and Gauld 1988) were done between the time Alayo and Fernández works were done, adding six new species to Cuban Ophioninae. If these records are not added to the work of Alayo then the increase rate is from 14 up to 34 (243\%), which in turn would mean the existence of more than 430 Ichneumonidae species for Cuba. However, it should be kept in mind that lesser is known of the large subfamilies (eg Banchinae, Cryptinae, Ichneumoninae, Pimplinae) than of Ophioninae, and therefore their percentages are also expected to increase.

Based on present information, and regardless of method used, 400-600 species appear to be a reasonable and rather conservative estimate of Cuban Ichneumonidae diversity. This means that what has been currently identified represents just $30-45 \%$ of what is actually expected in the archipelago. 


\section{ACKNOWLEDGMENTS}

JLFT is especially grateful to David Wahl (American Entomological Institute, USA) and Ian Gauld (British Museum, UK) for their comments and suggestions on a previous draft. Jesús Ugalde and Carolina Godoy (Instituto Nacional de Biodiversidad, Costa Rica), Paul Hanson (Universidad de Costa Rica), Ian Gauld and David Wahl sent very valuable references that allowed identification of Cuban Ichneumonidae. All curators of Cuban collections kindly loaned materials, but we are especially grateful to Tony Genaro (MNHNCu), Luis de Armas (IES) and Eduardo Portuondo (BIOECO).

\section{RESUMEN}

Se analiza el conocimiento actual acerca de los icneumónidos de Cuba (Hymenoptera: Ichneumonoidea); y se informan por primera vez para el país una subfamilia (Tersilochinae), 13 géneros y dos especies. El grupo es poco conocido por la carencia de taxónomos locales y el uso frecuente de métodos de recolección entomológica que no están dirigidos a este grupo. Usando los Ophioninae como referencia y comparando tanto con Costa Rica como con la cantidad de especies descritas a lo largo del tiempo, estimamos que el total de especies de Ichneumonidae en Cuba puede estar entre las 400 y 600 especies.

Palabras clave: Ichneumonidae, taxonomía, biodiversidad, Cuba.

\section{REFERENCES}

Alayo, P. 1973. Catálogo de los Himenópteros de Cuba. Instituto Cubano del Libro, La Habana, Cuba. 218 p.

Alayo, P. \& G. Tzankov. 1974a. Revisión de la familia Ichneumonidae en Cuba, I. Ser. Biol. 51: 1-23.

Alayo, P. \& G. Tzankov. 1974b. Revisión de la familia Ichneumonidae en Cuba, III. Ser. Biol. 54: 1-21.

Anonymous. 1984. Listado faunístico de la Cordillera de la Gran Piedra. Dpto. Técnico. Esfera de Áreas Protegidas. Parque Baconao-Turquino, Cuba. 30 p.

Arrianza, I. \& O. Melián. 1983. Estudio faunístico preliminar de Limoncitos. BSc. Thesis, Universidad de Oriente, Santiago de Cuba, Cuba.
Botta, A. \& N. Viña. 1982. Palma Mocha: estudio faunístico preliminar. BSc. Thesis, Universidad de Oriente, Santiago de Cuba, Cuba.

Dasch, C. 1974. Neotropic Mesochorinae. (Hymenoptera: Ichneumonidae). Mem. Am. Ent. Inst. 22: 500 p.

Fernández, J. 1994. Estudio de la composición faunística y algunos aspectos ecológicos del Orden Hymenoptera en el Jardín Botánico de Santiago de Cuba. BSc. Thesis, Universidad de Oriente, Santiago de Cuba. 67 p.

Fernández, J. 2002. A step forward: a new Catalog of Cuban Hymenoptera. Int. Soc. Hym Newslet. 3: 1.

Fernández, J. \& E. Portuondo. 2001. Estado actual del conocimiento sobre la Familia Braconidae (Hymenoptera) en Cuba, y nuevos registros para el país. Cocuyo 10: 6-7.

Fernández, J., H. Sariol, M. Vega, S. Ricardo, M. González \& E. Portuondo. 2002. Datos preliminares sobre la biodiversidad del Orden Hymenoptera en la provincia Granma, Cuba. Bol. Soc. Entomol. Aragonesa. 31: 43-48.

Fernández, J. (2005). Los inventarios de himenópteros (Insecta: Hymenoptera) en Cuba: Logros, limitaciones y perspectivas futuras. Bol. Soc. Entomol. Aragonesa. 36: 201-206.

Fernández-Triana, J.L. 2005. The taxonomy and biogeography of Cuban Ophioninae (Hymenoptera: Ichneumonidae). Zootaxa 1007: 1-60.

García, I., R. Alayo, N. Novoa, A. Nicholas, R. González, et al. 1973. Informe del Trabajo Faunístico Realizado en el Plan Jibacoa - Cayajabos. Serie Biológica 43.

Gauld, I. 1988. A survey of the Ophioninae (Hymenoptera: Ichneumonidae) of tropical Mesoamerica with special reference to the fauna of Costa Rica. Bull. Brit. Mus. (Natur. Hist.) Entomol. 57: 1-309.

Gauld, I. 1991. The Ichneumonidae of Costa Rica, 1. Mem. Amer. Entomol. Inst. 47: 1-589.

Gauld, I. 1997. The Ichneumonidae of Costa Rica, 2. Mem. Amer. Entomol. Inst. 57: 1-485.

Gauld, I. 2000. The Ichneumonidae of Costa Rica, 3. Mem. Amer. Entomol. Inst. 63: 1-453.

Gauld, I. \& D. Janzen. 2004. The systematics and biology of the Costa Rican species of parasitic wasps in the Thyreodon genus-group (Hymenoptera: Ichneumonidae). Zool. J. Linn. Soc. 141.

Gauld, I., J. Ugalde \& P. Hanson. 1998. Guía de los Pimplinae de Costa Rica. Rev. Biol. Trop. 46 (Suppl. 1): 1-189. 
Gauld, I, C. Godoy, R. Sithole \& J. Ugalde. 2002. The Ichneumonidae of Costa Rica, 3. Mem. Amer. Entomol. Inst. 66: 1-768.

Hanson, P. \& I. Gauld. 1995. Hymenoptera of Costa Rica. Oxford University, Oxford, England. 893 p.

Hochmut, R. \& D. Manso. 1975. Protección contra las plagas forestales en Cuba. Instituto Cubano del Ambiente, La Habana, Cuba. 290 p.

Marsh, P., S. Shaw \& R. Wharton. 1987. An identification manual for the North American genera of the family Braconidae (Hymenoptera). Mem. Entom. Soc. Washington. 13: 1-98.

Porter, C. 1984. Laticinctus group Thyreodon in the northen Neotropics. Wasmanian J. Biol. 42: 40-71.

Portuondo, E. 1998. Hymenoptera, p. 627-646. In BIOECO, CITMA (eds.). Diversidad Biológica del macizo montañoso Nipe-Sagua-Baracoa. BIOECO, La Habana, Cuba.

Portuondo, E. 2001. Himenópteros de Sierra Maestra. In BIOECO, CITMA (eds.). Diversidad biológica del Macizo Montañoso Sierra Maestra. BIOECO, La Habana, p. 519 - 532.

Portuondo, E., J. Fernández \& G. Garcés. 1994. Composición del Orden Hymenoptera presente en el Jardín Botánico de Santiago de Cuba. Biodversidad de Cuba Oriental 1: 19-24.

Portuondo, E. \& G. Garcés. 1994. Representantes del Orden Hymenoptera en un agroecosistema cañero. Biodiversidad de Cuba Oriental 1: 25-29.

Portuondo, E. \& J. Fernández. 2003. Sistemática de los himenópteros de Cuba: estado de conocimiento y perspectivas. Bol. Soc. Entomol. Aragonesa. 33: 101-112.

Townes, H. \& M. Townes. 1966. A catalogue and reclassification of Neotropic Ichneumonidae. Mem. Amer. Entomol. 8: 1-367.

Townes, H. 1960. Ichneumonflies of America North of Mexico: 2. Subfamilies Ephialtinae, Xoridinae, Acaenitinae. U. S. Nat. Mus. Bull. 216: 1-676.

Townes, H. 1969. The genera of Ichneumonidae, part 1. Mem. Amer. Entomol. 11: 1-300.

Townes, H. 1970a. The genera of Ichneumonidae, part 2.Mem. Amer. Entomol. 12: 1-537.

Townes, H. 1970b. The genera of Ichneumonidae, part 3. Mem. Amer. Entomol. 13: 1-307.

Townes, H. 1971. The genera of Ichneumonidae, part 4. Mem. Amer. Entomol. 17: 1-372.

Tzankov, G. \& P. Alayo. 1974. Revision of the Family Ichneumonidae in Cuba, II (Subfamily Gelinae). Reichenbachia 18: 117-138.

Wharton, R., P. Marsh \& M. Sharkey. 1998. Manual para los géneros de la Familia Braconidae (Hymenoptera) del Nuevo Mundo. The International Society of Hymenopterists, Washington, DC, USA. 447 p.

\section{INTERNET REFERENCES}

Wahl, D. 1999. Classification and Systematics of the Ichneumonidae (Hymenoptera). (Downloaded: February 20, 2006, http://iris.biosci.ohio-state.edu/ catalogs/ichneumonids/). 
